\title{
The Required Records Doctrine: Its Lessons for the Privilege Against Self- Incrimination
}

\author{
Stephen A. Saltzburg†
}

\section{The Controversial Privilege}

The Supreme Court has waxed eloquent about the importance of the privilege against self-incrimination to a free society. It has said that the privilege "registers an important advance in the development of our liberty" and that "[i]t reflects many of our fundamental values and most noble aspirations." In its famous opinion applying the privilege to custodial interrogation, Miranda $v$. Arizona, ${ }^{3}$ the Court wrote:

[W] may view the historical development of the privilege as one which groped for the proper scope of governmental power over the citizen. As a "noble principle often transcends its origins," the privilege has come rightfully to be recognized in part as an individual's substantive right, a "right to a private enclave where he may lead a private life. That right is the hallmark of our democracy."4

Yet, one week after it decided Miranda, the same Supreme Court held that the involuntary seizure of a blood sample from a person arrested for driving under the influence of alcohol did not violate the privilege. ${ }^{5}$ The Court conceded that "[i]f the scope of the privilege coincided with the complex of values it helps to protect, we might be obliged to conclude that the privilege was violated," but concluded that "the privilege has never been given the full scope which the values it helps to protect suggest."

It must be considered odd, to say the least, that the highest

$\dagger$ Professor of Law, University of Virginia.

1 Ullmann v. United States, 350 U.S. 422, 426 (1956) (Frankfurter, J.).

2 Murphy v. Waterfront Comm'n, 378 U.S. 52, 55 (1964) (Goldberg, J.).

3384 U.S. 436 (1966).

4 Id. at 460 (Warren, J.) (quoting United States v. Grunewald, 233 F.2d 556, 579, 58182 (2d Cir. 1956) (Frank, J., dissenting), rev'd, 353 U.S. 391 (1957)).

Schmerber v. California, 384 U.S. 757 (1966) (Brennan, J.).

B Id. at 762. 
court in the land explicitly recognized the privilege against selfincrimination as a "hallmark of our democracy" and almost in the same breath chose to interpret it so that its full scope is denied. Odd though it is, there can be no doubt that while the privilege gives rise to grand statements by distinguished commentators as well as by the Court, ${ }^{7}$ judicial interpretations of the privilege frequently are less grand. The limitations they invoke, although defensible, do not flow ineluctably from the history or language of the fifth amendment. ${ }^{8}$

This difficulty in reaching a definitive understanding of the privilege derives partly from its radical evolution over the centuries. Looking back at the English history of the privilege, one finds that it grew from a claim that no one should be held to answer questions under oath before being formally charged to a broad assertion that no person may be required to provide evidence against himself. ${ }^{9}$ As the scope of the privilege expanded, its utility and ethical soundness became controversial. Jeremy Bentham leveled a mighty attack against the privilege, ${ }^{10}$ and there have been doubts about its utility since. Wigmore defended the privilege, ${ }^{11}$ but his

7 See, e.g., Erwin Griswold, The Frtrth Amendment Today 7 (1955) (referring to the privilege as "one of the great landmarks in man's struggle to make himself civilized"). Griswold's statement has been cited favorably on several occasions by the Supreme Court. See, e.g., Murphy v. Waterfront Comm'n, 378 U.S. 52, 55 (1964); Ullmann v. United States, 350 U.S. 422,426 (1956).

- For example, in Schmerber the Court held that the privilege protects only "communications" or "testimony," but not "real or physical evidence" which the suspect is forced to provide. 384 U.S. at 764 . Language forbidding compulsion to make a person a witness against himself does not obviously require that result. In Bellis v. United States, 417 U.S. 85 (1974), the Court denied a former partner in a small law firm the right to claim the privilege with respect to firm documents. This result also is not clearly dictated by the language of the amendment, and in fact differs from the approach the Court originally took to partnership records in Boyd v. United States, 116 U.S. 616 (1886).

Boyd may represent the American high-water mark for the privilege. Boyd prohibited compulsory process against private business records-even those of a partnership-under both the fourth and fifth amendments. This prohibition extended not only to criminal actions, but also to civil actions which, like forfeiture, can be viewed as "in substance and effect . . . criminal one[s]." Id. at 634. Boyd's fifth amendment holding has been undermined by cases denying the privilege to all business enterprises but sole proprietorships, see infra notes 149-72 and accompanying text, and by cases holding that the act of producing private papers must be incriminating, independent of their content, see infra notes 175-81 and accompanying text. Its fourth amendment foundation has been weakened by the abandonment of the "mere evidence" rule in Warden v. Hayden, 387 U.S. 294, 300-10 (1967).

- See Leonard Levy, Origins of the Fifth Amendment 329-30 (1968); cf. Lewis Mayers, Shall We Amend the Fifth Amendment? 178-82 (1959) (suggesting that a witness should not be able to claim the privilege).

105 Jeremy Bentham, Rationale of Judicial Evidence 207-83 (London 1827).

118 John Wigmore, Evidence in Trials at Common Law § 2251, at 308 (3d ed. 1940). 
defense has been assailed as unpersuasive. ${ }^{12}$ One of the strongest attacks on the privilege argues that it defies basic notions of decent conduct. ${ }^{13}$

Ironically, the privilege has become even more controversial, and has been interpreted less generously by modern courts, at the same time as other constitutional protections have been allowed to blossom. Yet this result makes historical sense. When the privilege stood as protection of religious freedom and free speech, ${ }^{14}$ it served a noble purpose which the first amendment now more directly serves. When the privilege stood as a barrier to the use of torture and physical abuse to compel self-accusation, ${ }^{15}$ it was at its most defensible. Now basic concepts of due process outlaw brutal and even merely psychologically coercive methods of extracting confessions. ${ }^{16}$ The privilege is now invoked in circumstances which create the impression that it is no longer a great protection of civilized people, but a safe harbor for those who break society's rules. Such an impression is unlikely to produce generous readings of constitutional language.

It is thus not surprising to see courts straining to find that incriminating statements are not compelled ${ }^{17}$ or that compelled statements are not incriminating. ${ }^{18}$ Recent decisions that read the privilege narrowly are not necessarily wrong. These decisions inevitably involve line drawing, and reasonable minds will differ as to

12 See, e.g., Meltzer, Required Records, the McCarran Act, and the Privilege Against Self-Incrimination, 18 U. CHI. L. REv. 687, 689-99 (1951).

1s See Friendly, The Fifth Amendment Tomorrow: The Case for Constitutional Change, 37 U. CIN. L. REv. 671, 680 (1968).

16 See L. LEvy, supra note 9 , at 332 .

15 See id. at 326-27.

${ }^{16}$ See, e.g., Spano v. New York, 360 U.S. 315 (1959) (use of continuous interrogation through the night, along with police inducement of the suspect's close friend to lie to him, to extract confession is denial of due process); Brown v. Mississippi, 297 U.S. 278 (1936) (use of whipping and hanging from a tree to extract confession is denial of due process).

${ }_{17}$ The best recent example is Minnesota v. Murphy, 465 U.S. 420 (1984), where the Supreme Court found that a probationer, who was told that one condition of probation was that he must answer his probation officer's questions honestly, was held not to have been compelled to answer her questions. Id. at 429 . The Court argued that a reasonable person would have known that the condition only applied if Murphy chose to answer; it did not require an answer. Id. at 438 . But surely a reasonable person could have thought that a requirement that questions be answered honestly includes a requirement that questions actually be answered.

${ }^{18}$ See, e.g., California v. Byers, 402 U.S. 424, 427-31 (1971). In Byers, Chief Justice Burger wrote a plurality opinion which held that a "hit and run" reporting statute does not involve substantial risk of incrimination. A majority of the Court disagreed. See id. at 43435 (Harlan, J., concurring); id. at 460-61 (Black, J., dissenting); id. at 470 (Brennan, J., dissenting). 


\section{where the lines should be drawn. ${ }^{19}$}

Modern courts have also sought to limit the social costs of the privilege. The privilege has never been an absolute protector of privacy, despite the grand statements of the Miranda court. The government has always had the power to demand testimony in exchange for a grant of immunity. What has changed through time is the price the government must pay for the information it can demand. The Court's initial understanding was that the fifth amendment required a grant of "transactional immunity," which would free the witness from threat of prosecution for any crimes related to his testimony. The Court now holds that the privilege requires only "use immunity" and "derivative use immunity," which insulate a witness only from the use of his testimony and its fruits in later prosecutions. ${ }^{20}$ Again, this view is certainly plausible, espe-

10 For instance, it appears perfectly permissible for the government to indicate that it is investigating a person, even though the indication might put pressure on the suspect to speak. If this is permissible, is there a point at which the government's pressure amounts to compulsion? Miranda v. Arizona, 384 U.S. 436 (1966), clearly shows that there is. But it would be hard to say that Miranda identifies the precise point at which compulsion arises. The dissenters did not believe that custodial interrogation was inherently coercive. Surely there are others who believe that any interrogation, whether or not done in a custodial surrounding, amounts to compulsion of a suspect to speak.

As to limiting the kinds of evidence protected by the privilege, it appears that even under the most protective decision of all, Boyd v. United States, 116 U.S. 616 (1886), contraband could be seized from and used as evidence against an accused. The law has developed to the point where it is likely that almost any evidence validly seized under the fourth amendment may be used against a defendant. See United States v. Doe, 465 U.S. 605 (1984). The Supreme Court now reasons, as did Justice Holmes in Holt v. United States, 218 U.S. 245, 252-53 (1910) (no privilege against being compelled to model a blouse), that the privilege does not bar the use of evidence that is not the product of testimonial communication compelled from the accused. The Court recognizes, however, that a suspect may raise the privilege if the act of responding to a subpoena is itself an implicitly incriminating communication. See Doe, 465 U.S. at 612-13 (1984) (act of producing business records "testimonial" and "incriminating"); Fisher v. United States, 425 U.S. 391, 410-11 (1976) (act of producing accountant's workpapers not "testimonial self-incrimination"). But the Court has compelled compliance with subpoenas for such things as voice exemplars, which arguably require a suspect implicitly to represent his ordinary voice. United States v. Dionisio, 410 U.S. 1, 5-7 (1973); see also Gilbert v. California, 388 U.S. 263, 266-67 (1967) (handwriting exemplar not privileged); United States v. Wade, 388 U.S. 218, 221-23 (1967) (compelling defendant in a police lineup to repeat words that robber used not a violation of fifth amendment).

Decisions like Minnesota v. Murphy, 465 U.S. 420 (1984), discussed supra note 17, are difficult to defend. But other cases involving similar situations raise close questions. See, e.g., Oregon v. Mathiason, 429 U.S. 492 (1977) ("inviting" parolee to police station to talk to officer not fifth amendment violation).

${ }^{20}$ Under the doctrine of Counselman v. Hitchcock, 142 U.S. 547 (1892), immunity may only supplant the privilege if the breadth of the grant of immunity is equal to that of the privilege. Until Kastigar v. United States, 406 U.S. 441 (1972), the privilege was thought to require transactional immunity. Kastigar held that use and derivative use immunity were 
cially because no absolute standards exist by which to measure the accuracy of the balance struck by alternative understandings of the privilege.

Decisions that are more difficult to explain and to defend involve what has become known as the "required records" doctrine. These decisions hold that under some circumstances a person may be required by law-subject to criminal sanction-to communicate in writing with government officials even though the communications themselves might be incriminating enough to support a criminal conviction. The doctrine developed at a time when the Court assumed that the government could not subpoena the self-incriminatory private papers of an individual who has the right to claim the privilege. ${ }^{21}$ The doctrine invites the government to require individuals to keep the kinds of records it most wants to subpoena and to claim that these "required records" are not privileged, thereby circumventing constitutional limitations on compulsory record-keeping and production of documents.

Three and a half decades ago, Professor Meltzer used these pages to examine the required records doctrine and the privilege against self-incrimination. ${ }^{22} \mathrm{He}$ concluded that the doctrine "marks a shift in the relationship of the citizen to his government" that it did not cause. The shift "is an incident of the pervasive expansion of the government's regulatory and revenue powers"; the required records doctrine "merely recognizes that the government, having assumed far-reaching tasks, must be given appropriate investigatory powers." ${ }^{\text {"23 }}$ Other writers have expressed greater doubts about the doctrine. ${ }^{24}$ It appears, however, that the courts have largely agreed with Professor Meltzer, for the doctrine has shown considerable staying power.

The longevity of the required records doctrine is, of course, not proof of its wisdom. The framers of the privilege could no more have envisioned how the privilege might operate amidst the complex regulatory apparatus of twentieth-century America than they

\footnotetext{
adequate safeguards. Id. at 448-53.

${ }^{21}$ This principle seems to have originated with Boyd v. United States, 116 U.S. 616, 630 (1886).

${ }^{23}$ See Meltzer, supra note 12.

${ }^{23}$ Id. at 728.

24 See, e.g., Mansfield, The Albertson Case: Conflict Between the Privilege Against Self-Incrimination and the Government's Need for Information, 1966 Sup. CT. REv. 103, 166 (doctrine may cause us to lose sight of "subtle but important values"); McKay, SelfIncrimination and the New Privacy, 1967 SuP. CT. REv. 193, 217 (required records doctrine may swallow the privilege whole with respect to written documents).
} 
could have anticipated dogs trained to sniff out marijuana ${ }^{25}$ or a host of other problems that modern technology raises under the fourth amendment. ${ }^{26}$ To assess the required records doctrine, it is thus necessary to examine how it developed, the limits that have been placed upon it, and the effect that it has had on the privilege against self-incrimination. Such an examination may do more than promote an understanding of the doctrine; it may also tell us much about the place of the privilege against self-incrimination in the modern world.

\section{Development of the Required Records Doctrine}

\section{A. The Most Important Case-Shapiro v. United States}

William Shapiro, a wholesaler of fruit and produce during the Second World War, was subject to the licensing provisions of the Emergency Price Control Act. ${ }^{27}$ A regulation under the Act required that licensees keep price, sale, and delivery records and make them available for administrative inspection. The Act stated that the privilege against self-incrimination did not excuse noncompliance, but also incorporated the immunity provisions of the Compulsory Testimony Act of $1893{ }^{28}$ Under the 1893 Act, compliance with a subpoena resulted in immunity from prosecution to whatever extent required by the privilege against selfincrimination. ${ }^{29}$

Shapiro was directed by subpoena to produce " "all duplicate sales invoices, sales books, ledgers, inventory records, contracts and records relating to the sale of all commodities from September 1st, 1944, to September 28, 1944." "\$30 $\mathrm{He}$ complied with the subpoena, but claimed his constitutional privilege. Nevertheless, the government prosecuted Shapiro for illegal tie-in sales that violated the emergency statute. In response, Shapiro alleged that the prosecution was barred by the immunity provisions of the Price Control

${ }^{26}$ See, e.g., United States v. Place, 462 U.S. 696 (1983).

28 See, e.g., Katz v. United States, 389 U.S. 347 (1967) (modern eavesdropping equipment and the "reasonable expectation of privacy").

${ }^{27}$ Ch. 26, § 205(f), 56 Stat. 23, 34-35 (1942) (repealed 1947).

${ }^{28}$ Ch. 83, 27 Stat. 443, 444 (repealed 1978). Section 202(g) of the Emergency Price Control Act, 56 Stat. at 30, provided that the Compulsory Testimony Act would apply to any individual who specifically claimed the privilege.

29 The 1893 statute provided that no person shall be prosecuted or subjected to any penalty or forfeiture "for or on account of any transaction, matter or thing, concerning which he may testify, or produce evidence, documentary or otherwise, before said commission, or in obedience to its subpoena." Ch. 83,27 Stat. at 444.

so Shapiro v. United States, 335 U.S. 1, 4 (1948) (quoting the subpoena). 
Act because the government's criminal investigation was based on the subpoenaed information and leads therefrom. ${ }^{31}$

The court of appeals held that the Act's immunity provisions applied only if Shapiro had a valid claim of self-incrimination with respect to the subpoenaed records, and that Shapiro had no such claim. Since Shapiro was required by law to keep the records, they were found to be "public" documents falling outside the reach of the fifth amendment claim that attached to "private" papers. ${ }^{32}$

The Supreme Court affirmed. The point which is rarely mentioned about the case is that Chief Justice Vinson, writing for the Court, devoted the vast majority of his opinion to the construction of the immunity provisions in the legislation, not to the constitutional question raised by the required records doctrine. He found a clear congressional intent to use the record-keeping and inspection requirements not only to obtain information but also to aid law enforcement. ${ }^{33}$ Thus, he concluded that Congress "could [not] have intended private privilege to attach to records whose keeping it authorized the Administrator to require," and that "[i]t is difficult to believe that Congress ... could possibly have intended [the immunity provision] to proffer a 'gratuity to crime' by granting immunity to custodians of nonprivileged records."

Shapiro had offered an argument which reconciled congressional intent to aid law enforcement with a broad reading of the privilege. Under Wilson $v$. United States, ${ }^{35}$ corporations and their officers could not claim the privilege with respect to corporate

${ }^{31}$ Id. at 3-5.

${ }^{32}$ United States v. Shapiro, 159 F.2d 890, 892 (2d Cir. 1947). The court of appeals found that the records were required by a valid regulation under the Price Control Act, section 14 of Maximum Price Regulation 426, 8 Fed. Reg. 9546 (1943). That regulation provided that every person subject to it shall preserve for examination "all his records, including invoices, sales tickets, cash receipts, or other written evidences of sale or delivery which relate to the prices charged pursuant to the provisions of this regulation." It also provided that every person subject to the act shall keep and make available "records of the same kind as he has customarily kept, relating to the prices which he charges for fresh fruits and vegetables after the effective date of the regulation and in addition as precisely as possible, the basis upon which he determined the maximum prices for these commodities." Id. at 954849. Arguably, the subpoena went beyond the records required to be kept in seeking "records relating to the sale of all commodities." This is broader language than that found in the regulation.

${ }^{33}$ Shapiro, 335 U.S. at 8.

34 Id. at 15. Several earlier cases, some of which are examined infra at notes $150-88$ and accompanying text, held that certain records may be compelled by subpoena. But those cases involved corporations and other entities. Shapiro is significant because it applies to individuals. It may be that Shapiro does more to explain the earlier cases than they do to explain Shapiro.

ss 221 U.S. 361 (1911). 
records. Congress could thus have intended to require corporations to keep records to aid enforcement of the Act without running afoul of the privilege. Shapiro argued that Congress must have intended that individuals, whose records were privileged, be treated differently from corporations for law enforcement purposes.

The Court rejected this argument. ${ }^{36}$ In its view, the rationale of Wilson was not that corporations and their officers may not invoke the privilege. Rather, Wilson stood for the proposition that the privilege did not attach to corporate documents because they were required by law to be kept for the public benefit. ${ }^{37}$ This rationale, the Court argued, applies with equal force to the records of individuals engaged in regulated businesses.

After reaching this conclusion, the Chief Justice disposed of the argument that this construction of the statute raised serious constitutional questions:

It may be assumed at the outset that there are limits which the Government cannot constitutionally exceed in requiring the keeping of records which may be inspected by an administrative agency and may be used in prosecuting statutory violations committed by the record-keeper himself. But no serious misgiving that those bounds have been overstepped would appear to be evoked when there is a sufficient relation between the activity sought to be regulated and the public concern so that the Government can constitutionally regulate or forbid the basic activity concerned, and can constitutionally require the keeping of particular records . . . .

In the portion of his opinion discussing the constitutional question, the Chief Justice cited almost no authority. It was earlier in the opinion, in the discussion of the immunity provision, that he had relied on Wilson. ${ }^{39}$ His most important citation here was to Davis $v$. United States, ${ }^{40}$ in which the Court had upheld a warrantless search for gasoline ration coupons in part because the coupons in Davis's possession were found to be government property and that therefore "normal restraints on intrusion on one's privacy

36 It appears that the Court treated the argument as one of statutory interpretation. The Chief Justice did not return to it when he considered constitutional objections to the Court's interpretation of the immunity provision.

${ }^{37}$ Shapiro, 335 U.S. at $16-18$ \& n.24.

38 Id. at 32 . These words have often been quoted. See, e.g., McKay, supra note 24, at 217 n.100; Meltzer, supra note 12, at 714.

38 See Shapiro, 335 U.S. at 16-24.

328 U.S. 582 (1946). 
... are relaxed." ${ }^{11}$ Davis is much more a fourth than a fifth amendment case; the decision rested in large part on a finding that Davis consented to turning over the documents. ${ }^{42}$ Thus, neither Davis nor Wilson gave precedential support to the constitutional position taken in Shapiro. Both cases did, however, provide language for the Shapiro Court to cite in its effort to distinguish public from private papers. ${ }^{43}$

Justice Frankfurter, who had vigorously dissented in Davis, did so again in Shapiro. ${ }^{44}$ Indeed, his opinion may have made Shapiro even more important than it otherwise would have been, for he broadly stated that "[i]n an almost cursory fashion, the Court needlessly decides that all records which Congress may require individuals to keep in the conduct of their affairs, because they fall within some regulatory power of Government, become 'public records' and thereby, ipso facto, fall outside the protection of the Fifth Amendment."45

The heart of the dissent is its concern that "[i]f records merely because required to be kept by law ipso facto become public records, we are indeed living in glass houses." ${ }^{46}$ Justice Frankfurter observed the extensive record-keeping requirements in federal law and made reference as well to state and local legislation. ${ }^{47}$ $\mathrm{He}$ accepted the idea that "[i]f the records in controversy here are in fact public, in the sense of publicly owned, or governmental, records, their nonprivileged status follows," but he chose the word "startling" to describe "the notion that whenever Congress requires an individual to keep in a particular form his own books dealing with his own affairs his records cease to be his when he is accused of crime." ${ }^{48} \mathrm{He}$ argued strenuously that if the records were actually public, "the public should . . . have the same right that the Government has to peruse, if not to use, them." he concluded that "the authorities give no support to the broad proposition that because records are required to be kept by law they are public records and, hence, nonprivileged." "While law

4 Id. at 593.

42 Id. The fourth amendment orientation of Davis is also evident in the strong dissent by Justice Frankfurter, joined by Justice Murphy. Id. at 594-623.

43 See Shapiro, 335 U.S. at 34.

4. Id. at 36-70 (Frankfurter, J., dissenting).

45 Id. at 37 .

48 Id. at 51 .

47 Id. at 51-53.

48 Id. at 54 (emphasis in original).

49 Id. at 55 .

${ }^{\circ 0}$ Id. at 64 . 
enforcement officers may find their duties more arduous and crime detection more difficult as society becomes more complicated, the constitutional safeguards of the individual were not designed for short-cuts in the administration of criminal justice."5I

Justice Jackson, joined by Justice Murphy, also dissented. $\mathrm{He}$ expressed concern that "[ $t$ ]oday's decision introduces a principle of considerable moment." Although he recognized that the decision "strips of protection only business men and their records," he observed that "we cannot too often remind ourselves of the tendency of such a principle, once approved, to expand itself in practice 'to the limits of its logic." "\$s3

\section{B. The Next Step-Kahriger and Lewis}

Shapiro was a wartime case in which the Court might well have been influenced in its assessment of constitutional principles by a sense of public urgency. ${ }^{54}$ One can only speculate as to whether the decision would have proved to be of long-run importance had Justice Frankfurter's dissent responded to a narrower interpretation of the decision. Whatever the answer, Congress assured that Shapiro would have lasting significance when it interpreted the Court's new doctrine broadly and enacted the Internal Security Act of $1950^{55}$ and the Revenue Act of $1951 . .^{56}$

Portions of the Revenue Act gave the Court its first chance to address the implications of Shapiro. The Revenue Act required persons in the business of accepting wagers to register with the Collector of Internal Revenue and to pay a yearly $\$ 50$ occupational tax. In United States $v$. Kahriger, ${ }^{87}$ the Court upheld the tax and registration provisions as valid uses of federal taxation power, even though the federal government was thought to be without power to regulate gambling directly. ${ }^{58}$ The Court also rejected Kahriger's

st Id. at $69-70$.

s2 Id. at 70 (Jackson, J., dissenting).

ss Id.

st Cf. Korematsu v. United States, 323 U.S. 214 (1944) (holding constitutional a World War II executive order excluding persons of Japanese ancestry from the "West Coast military area").

ss Ch. 1024, 64 Stat. 987 (codified as amended at 50 U.S.C. $\S \S 781-858$ (1982)). Cases under this statute are discussed infra at notes 70-79 and accompanying text.

ss Ch. 521, 65 Stat. 452.

3734 U.S. 22 (1953).

ss Id. at 25-32. The assumption that Congress could not directly regulate gambling would probably not now be made in view of the Court's broad interpretation of Congress's powers under the commerce clause. 
self-incrimination challenge. ${ }^{50}$ Relying on Wigmore, ${ }^{60}$ the Court argued that Kahriger had no claim of privilege because "[u]nder the registration provisions of the wagering tax, appellee is not compelled to confess to acts already committed, he is merely informed by the statute that in order to engage in the business of wagering in the future he must fulfill certain conditions."

Justice Frankfurter again dissented. He argued that due process prevents Congress from seeking to compel self-incriminating disclosures "merely because [Congress is doing] so under the guise of a revenue measure obviously passed not for revenue purposes."62 Justice Jackson expressed greater empathy for Congress's purpose in enacting the statute and showed concern that "[s]weeping and undiscriminating application of the immunity doctrines to taxation would almost give the taxpayer an option to refuse to report, as it now gives witnesses a virtual option to refuse to testify." curred, "but with such doubt that if the minority agreed upon an opinion which did not impair legitimate use of the taxing power I probably would join it."

Kahriger provided the Court with all the authority that it needed two years later in Lewis $v$. United States. ${ }^{65}$ Lewis, like Kahriger, was charged with accepting wagers without paying the occupational tax. But Lewis's acts took place in the District of Columbia, which had a federal law against wagering. ${ }^{66}$ Thus, Lewis argued that, unlike Kahriger, he would incriminate himself under federal law if he complied with the statute. The Court rejected the argument, emphasizing that "[t]here is nothing compulsory" about the taxation statute, since Lewis need only choose whether to pay

69 While the Court ruled on the challenge, Justice Reed, writing for the majority, reasoned that Kahriger was poorly situated to make the challenge since he had in fact not registered for the wagering tax. 345 U.S. at 32.

so $8 \mathrm{~J}$. WigmoRe, supra note 11, § 2259 (c), para. (2) ("The generalization, therefore, may be made, that there is no compulsory self-incrimination in a rule of law which merely requires beforehand a future report on a class of future acts among which a particular one may or may not in future be criminal at the choice of the party reporting." (emphasis in original)). The Court also cited Davis and Shapiro. Kahriger, 345 U.S. at 33 n.13.

62 345 U.S. at 32-33.

${ }^{62}$ Id. at 40 (Frankfurter, J., dissenting).

${ }^{63}$ Id. at 34 (Jackson, J., concurring).

64 Id.

Gs 348 U.S. 419 (1955).

${ }^{66}$ Lewis thus did not involve the then unresolved question of the effect of a claim of privilege in federal proceedings on subsequent state criminal prosecutions. See United States v. Murdock, 284 U.S. 141, 149 (1931) (privilege does not bar state prosecution), overruled, Murphy v. Waterfront Comm'n, 378 U.S. 51, 78, 79 n.18 (1964) (privilege applies to state use of evidence). 
the tax or give up gambling. ${ }^{67}$ The Court also judged Lewis's distinction between federal and state law to be immaterial.

After the decisions in Kahriger and Lewis, Justice Frankfurter seemed correct in believing that Shapiro had adopted the startling proposition that "whenever Congress requires an individual to keep in a particular form his own books dealing with his own affairs his records cease to be his when he is accused of crime."68 Hypothetical cases were easily imagined and must have seemed quite real. Professor Meltzer suggested the following one: "Suppose, e.g., the federal government in order to enforce the Mann Act required the keeping of records of interstate excursions involving women." ${ }^{68}$ Did the Court really intend that this would be permissible? No answer was forthcoming, however, because the Court soon overruled Kahriger and Lewis. In the process it assuaged some fears and created some new confusions.

\section{Restricting the Scope of Shapiro}

\section{A. A First, Tacit Step-The McCarran Act Cases}

As noted earlier, even before Congress enacted the gambling registration and taxation statute, it had enacted a statute known as the Internal Security Act of 1950 or the McCarran Act. ${ }^{70}$ The Act imposed registration and record-keeping requirements on "Communist-action" and "Communist-front" organizations. ${ }^{71}$ More than a decade after the McCarran Act's passage, a sharply divided Supreme Court held in Communist Party v. Subversive Activities Control Board" that "[t]he Constitution does not prohibit the requirement that the Communist Party register with the Attorney General as a Communist-action organization."73 Justice Douglas complained in dissent that "[ $t]$ he sluice gates, opened a hair's width" in Kahriger and Lewis, were "now flung wide."

62 Lewis, 348 U.S. at 422.

6s Shapiro, 335 U.S. at 54 (Frankfurter, J., dissenting).

B9 Meltzer, supra note 12, at 714.

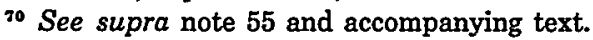

"Registration was governed by two sections of the Subversive Activities Control Act, Title I of the 1950 statute. Ch. 1024, $\$$ 7-8, 64 Stat. 987, 993-95 (repealed 1968). The Act required, inter alia, that party officers, directors and others sign a registration statement, and mandated disclosure of the names of persons who had been officers, directors or members of the party during the preceding 12 months.

72367 U.S. 1 (1961) (5-4 decision).

7s Id. at 115.

34 Id. at 184 (Douglas, J., dissenting). Justice Brennan, with whom Chief Justice Warren joined, also dissented. Id. at 200-02 (addressing fifth amendment claim). 
Four years later in 1965, however, the Court held in Albertson $v$. Subversive Activities Control Board ${ }^{75}$ that the provision of the McCarran Act requiring individuals to register as members of the Communist party violated the privilege against self-incrimination. The Court found "obvious" risks of incrimination associated with registration. ${ }^{76}$ There were no dissents. ${ }^{77}$

Fourteen years before Albertson, Professor Meltzer had suggested that the McCarran Act's registration requirements might be upheld under the required records doctrine, and that the doctrine itself might needlessly come under fire as a result. ${ }^{78}$ While Albertson did not mention the required records cases, the decision might well have been important in limiting the doctrine.

There were certainly distinctions between the reporting requirements of the McCarran Act and the Revenue Act. Most notably, the Court in Kahriger and Lewis had viewed the gambling provisions of the Revenue Act as requiring disclosure of intent to engage in the gambling business in the future. In this view, the privilege was unnecessary because a person could avoid self-incrimination simply by choosing not to enter that business. ${ }^{79}$ It might be possible to distinguish the McCarran Act as focusing on past membership in the Communist party. Were this distinction tenable, it might account for the Court's disinclination to invoke the required records doctrine in Albertson.

Under the "choice" theory developed in Kahriger and Lewis, however, this explanation of Albertson is not entirely satisfactory. Since Communist party members and officers had statutory warning that they might be required to register, it is arguable that

75382 U.S. 70 (1965).

${ }^{76}$ Id. at 77. There was an immunity provision in the McCarran Act, ch. 1024, § 4(f), 64 Stat. 987, 992 (1950), amended by Act of January 2, 1968, Pub. L. No. 90-237, § 3, 82 Stat. 765,765 (omitting immunity provision) (codified at 50 U.S.C. $§ 783(f)$ (1982)), but it was not broad enough to remove substantial possibilities of prosecution. See Albertson, 382 U.S. at $79-80$.

${ }^{27}$ Justice Clark filed a concurring opinion. 382 U.S. at 85. Justice Black concurred on the same grounds and on the first amendment grounds set forth in his dissenting opinion in Communist Party v. Subversive Activities Control Board, 367 U.S. 1, 137 (1961). See 382 U.S. at 82. Justice White did not participate.

${ }^{78}$ Meltzer, supra note 12, at 725-27.

79 See, e.g., Lewis v. United States, 348 U.S. 419,422 (1955) ("The only compulsion under the Act is that requiring the decision which would-be gamblers must make at the threshold. They may have to give up gambling, but there is no constitutional right to gamble."), cited with disapproval in Marchetti v. United States, 390 U.S. 39, 51 (1968) ("if such an inference of antecedent choice were alone enough to abrogate the privilege's protection, it would be excluded from the situations in which it has historically been guaranteed, and withheld from those who most require it"). 
party participation also involved a "choice." Thus, the failure of Albertson to rely on the required records doctrine seems to express a dissatisfaction with the doctrine, although Albertson's significance in limiting the doctrine is more apparent now than when the case was decided.

\section{B. The Major Step-Overruling Kahriger and Lewis}

The importance of Albertson to the required records doctrine soon became apparent. ${ }^{80}$ Just three years after deciding Albertson, the Court took an explicit look at the required records doctrine in a trilogy of cases decided on the same day: Marchetti $v$. United States, ${ }^{81}$ Grosso $v$. United States, ${ }^{82}$ and Haynes $v$. United States. ${ }^{83}$ Justice Harlan wrote for the Court in all three.

Marchetti and Grosso, like Kahriger and Lewis, involved taxation of the wagering business. In the first case, Marchetti had been convicted of conspiring to evade payment of the annual occupational tax, ${ }^{84}$ failing to pay the occupational tax, and failing to register. ${ }^{85}$ The lower courts correctly found Kahriger and Lewis controlling. ${ }^{86}$ Justice Harlan noted that the reasoning of those decisions was based on an understanding of the statutory requirements as purely prospective. Gamblers were viewed as registering their intent to be gamblers in the future, not their past gambling activities. Justice Harlan pointed out two defects in this reasoning: "first, it overlooks the hazards here of incrimination as to past or present acts; and second, it is hinged upon an excessively narrow view of the scope of the constitutional privilege." $87 \mathrm{He}$ found "[s]ubstantial hazards of incrimination as to past or present acts," and termed the "premise that the privilege is entirely inapplicable

so Only one year after Albertson, the Court granted review of the lower court decision in United States v. Costello, 352 F.2d 848 (2d Cir. 1965), vacated, 390 U.S. 201 (1968), to decide whether Kahriger and Lewis should be overruled in light of Albertson. When Costello died, the Court granted review of the same question, which had been addressed in the lower court's opinion in United States v. Marchetti, 352 F.2d 848 (2d Cir. 1965). After argument, the Court set the case for reargument and asked the parties also to address the relevance of Shapiro to the case. See Marchetti v. United States, 390 U.S. 39, 41 n.1 (1968).

81390 U.S. 39 (1968).

82390 U.S. 62 (1968).

8s 390 U.S. 85 (1968). These three cases will sometimes be referred to collectively as "the trilogy."

s4 See Internal Revenue Code of 1954 , ch. 736, § 4411, 68A Stat. 3, 527 (codified as amended at 26 U.S.C. § 4411 (1982)).

ss See Internal Revenue Code of 1954 , ch. 736, § 4412, 68A Stat. 3, 527 (codified as amended at 26 U.S.C. $\S 4412$ (1982)).

so Marchetti, 390 U.S. at 41.

87 Id. at 52 . 
to prospective acts" a "more fundamental deficiency."

Justice Harlan conceded that "[h]istory . . . offers no ready illustrations of the privilege's application to prospective acts," but he explained that "the occasions on which such claims might appropriately have been made must necessarily have been very infrequent." lege's application is whether the claimant is confronted with real and not imaginary risks of incrimination. While the selfincriminatory consequences of "confession[s] of a guilty purpose" would often be "speculative and insubstantial," this was not necessarily true of all prospective acts..$^{90}$ The real hazard of incrimination Justice Harlan found in Marchetti's case was that "[p]rospective registrants can reasonably expect that registration and payment of the occupational tax will significantly enhance the likelihood of their prosecution for future acts, and that it will readily provide evidence which will facilitate their convictions." Kahriger and Lewis were overruled to the extent that they precluded Marchetti from relying on the privilege against self-incrimination, and Marchetti's convictions were reversed.

In the second case of the trilogy, Grosso had been convicted of failure to pay the excise tax on wagers, ${ }^{22}$ failure to pay the occupational tax, ${ }^{93}$ and conspiracy to evade payment of both taxes. $\mathrm{He}$ focused in the Supreme Court on the excise tax convictions. ${ }^{94}$ Treasury regulations required wagerers to submit monthly forms to the Internal Revenue Service detailing their wagering activities. Monthly payment of the excise tax also was required, and payment could not be made without filing the form. Since the Service made the information on the form available to prosecuting authorities, the Court had no difficulty in finding substantial and real hazards of self-incrimination. ${ }^{95}$ Relying on Marchetti, Justice Harlan found

ss Id. at 52-53. The Court noted that the Kahriger Court's sole authority for this premise had been Wigmore. See supra note 60 and accompanying text.

${ }^{89}$ Marchetti, 390 U.S. at 53.

${ }^{90} \mathrm{Id}$. at 54 .

ol Id.

${ }^{92}$ See Internal Revenue Code of 1954, ch. 736, $\S 4401,68$ A Stat. 3, 525, amended by Excise Tax Technical Changes Act of 1958, Pub. L. No. 85-859, § 151, 72 Stat. 1275, 1304 (current version at 26 U.S.C. § 4401 (1982)).

${ }_{93}$ This statute was also considered in Marchetti. See supra note 84.

94 The Court noted that Grosso apparently felt foreclosed by Kahriger and Lewis from raising the fifth amendment issue as to the occupational tax. The Court refused to view his silence as a waiver, and it reversed the occupational tax conviction along with the others. Grosso, 390 U.S. at 71-72.

- ${ }^{95}$ Id. at 65-67. The law did not require the Service to make the information available to prosecuting authorities, but neither did it prohibit it. Id. at 66 . 
that the required records doctrine could not sustain the excise tax scheme. ${ }^{96}$

In the third case, Haynes $v$. United States, ${ }^{97}$ Haynes had been convicted of possessing an unregistered firearm in violation of the National Firearms Act. ${ }^{98}$ Justice Harlan parsed a complicated statutory scheme to conclude that Congress directed the registration requirement at persons who had obtained a firearm without complying with the Act's substantive requirements, which regulated the making and transfer of certain types of firearms. ${ }^{99}$ Although the Court accepted the government's representation that in certain "uncommon" situations a person who had not violated the substantive provisions of the Act might be required to register, it expressed no doubt that "the correlation between obligations to register and violations can only be regarded as exceedingly high," and that a prospective registrant "can reasonably fear that the possession established by his registration will facilitate his prosecution under the making and transfer clauses of [the Act]." 100 Finding reasonable grounds for Haynes to have feared incrimination, the Court stated that Marchetti and Grosso governed and reversed his conviction. ${ }^{101}$ Because there were situations in which registration would not create a substantial risk of incrimination, the Court declined to hold the statutory registration requirement invalid on its

${ }^{98}$ Chief Justice Warren was the lone dissenter, in an opinion that applied to both Grosso and Marchetti. 390 U.S. at 77. Justice Stewart added a one-paragraph opinion concurring with the majority, but stated that he would have joined the Chief Justice were $A l-$ bertson not controlling. 390 U.S. at 76-77. Justice Brennan also concurred, but added a separate opinion stating that he thought Grosso was consistent with Shapiro as well as with the earlier case of United States v. Sullivan, 274 U.S. 259 (1927) (upholding a conviction for failure to file a tax return where the privilege could be invoked as to specific self-incriminating parts of the return). 390 U.S. at 72 (Brennan, J., concurring). Sullivan is discussed infra at text accompanying notes 111-12.

${ }^{97} 390$ U.S. 85 (1968).

98 Internal Revenue Code of 1954, ch. 53, $\S 5801-62,68$ A Stat. 3, 721-29 (1954), amended by National Firearms Act Amendments of 1968, Pub. L. No. 90-618, 82 Stat. 1227 (current version at 26 U.S.C. $\$ \S 5801-72$ (1982)). The 1968 Amendments dramatically altered the registration provisions at issue in Haynes.

99 Haynes, 390 U.S. at 96.

${ }^{100}$ Id. at 96-97.

${ }^{101}$ Id. at 98-99. Chief Justice Warren again dissented based on the same concern expressed in his dissent to Marchetti and Grosso: the Court's opinions might have an adverse impact on Congress's ability to enact much-needed legislation. Id. at 101; cf. Grosso, 390 U.S. at 84 (Warren, C.J., dissenting).

Although the Supreme Court did not find it appropriate to read an immunity provision into the statute, Congress subsequently enacted such a provision. National Firearms Act Amendments of 1968, Pub. L. No. 90-618, § 5848, 82 Stat. 1227, 1232 (codified at 26 U.S.C. $\S 5848$ (1982)). The Supreme Court upheld the revised statute in United States v. Freed, 401 U.S. 601 (1971). 
face. Instead, it held that a proper claim of privilege would be a defense to a prosecution for failure to register or for possession of an unregistered firearm. ${ }^{102}$

\section{The Deficiencies in the Trilogy}

The trilogy came no closer than did Shapiro itself to specifying the limits of the required records doctrine. Justice Harlan made three distinctions between Shapiro and Marchetti that seemed on the surface to clarify the doctrine. First, unlike the situation in Shapiro, the kinds of documents required of Marchetti were not those which he had customarily kept. ${ }^{103}$ Second, whatever "public aspects" there were to Shapiro's records, Marchetti's had none. ${ }^{104}$ Finally, "the requirements at issue in Shapiro were imposed in 'an essentially noncriminal and regulatory area of inquiry' while those [involved in Marchetti were] directed to a 'selective group inherently suspect of criminal activities." "105 But a careful analysis of these points shows that they fail to distinguish the cases adequately, and that they cannot account for case law that the Court considers to be consistent with the trilogy.

Justice Harlan's first distinction was that the books and records which Shapiro was required to keep were of the type that he customarily kept. This is only partly true, however. The regulation also required that he keep certain other books and records, without regard to whether they were customarily kept. ${ }^{106}$ Both types were subpoenaed, and they were treated similarly by the Shapiro Court. ${ }^{107}$ Justice Harlan's tacit assumption that gamblers do not keep records is also subject to criticism. Is there reason to believe that gamblers who wager do not record what they owe and what is owed them? Surely gamblers do not want their records made public, and some may use code to prevent any third party from understanding the records. But it is not readily apparent that at least some of the records involved in Grosso, the wagering excise tax case, were less customary than those involved in Shapiro.

Furthermore, Justice Harlan failed to explain why "customary" records should warrant less protection than records uniquely required by the government. Records that are customarily kept

102 Haynes, 390 U.S. at 99.

${ }^{103}$ Marchetti, 390 U.S. at 57.

104 Id.

${ }^{105}$ Id. (quoting Albertson v. Subversive Activities Control Bd., 382 U.S. 70, 79 (1965)).

${ }^{206}$ See supra note 32.

${ }^{107}$ Shapiro, 335 U.S. at 4-5. 
might well be more personal and valuable to the person who has kept them sua sponte and thus might deserve maximum protection from government inspection. This argument has as much to commend it as has Justice Harlan's.

The second distinction suggested by Justice Harlan in Marchetti is that the records at issue in the trilogy, unlike the Shapiro records, had no "public aspect." It might be sufficient here simply to recall Justice Frankfurter's attack on the notion that the Shapiro records were "public."108 Certainly those records were not public in the sense that they were in the control of and readily available to all members of the public. Furthermore, whatever the concept of a "public record" might include, it would seem that the records in the trilogy come closer to it than the Shapiro records. After all, the records in the trilogy were actually to be filed with and possessed by the government, and some were to be made available to other people, especially law enforcement officials. The Shapiro records were privately kept and merely subject to subpoena and government inspection.

Justice Harlan's third distinction has greater merit. $\mathrm{He}$ observed that the requirements in the trilogy were directed at groups naturally suspected of criminal activity. In the gambling cases, the Court makes a strong case that most wagering was illegal and that most of the people who were called upon to register and pay taxes were virtually conceding their involvement in illegal activity. ${ }^{109}$ But is it equally true that persons who use and possess firearms are a suspect group generally thought to be criminal? While the Haynes Court thought that only "gangsters" used the regulated firearms, there is reason to doubt the accuracy of that assumption..$^{110}$

To fit Haynes into Justice Harlan's analysis, it is necessary to focus on the particular people who would be called upon to register under the specific provision of the federal statute. These people typically would be in violation of the statute and thus the reporting requirement imposed upon them comes close to the other cases in the trilogy. But if attention is paid to the persons whom the government calls upon to produce their books and records, then is Haynes really so different from Shapiro? Shapiro might have successfully argued that the government sought inspection and pro-

${ }^{108}$ See supra notes 44-51 and accompanying text.

109 See Marchetti, 390 U.S. at 44-46.

110 The Haynes Court relied on unsubstantiated congressional statements that the taxed weapons were of a type used principally by criminals. 390 U.S. at $87 \&$. .4 . 
duction of records only from those suspected of criminal acts, and that it was the selective inspection and production, not simply the universal record-keeping requirement, that amounted to a violation of the privilege.

Even assuming, however, that Justice Harlan's three points do distinguish the trilogy from Shapiro, they nonetheless fail to account for the 1927 case of United States $v$. Sullivan. ${ }^{111}$ In Sullivan, the Court upheld a conviction for failure to file a tax return. In dicta, however, Justice Holmes implied that the privilege against self-incrimination could be invoked by one who refused to give some of the information required by the return. ${ }^{112}$ Sullivan certainly is at odds with the points later emphasized in the trilogy. A federal tax return is the classic example of a record that is required of almost everyone, not merely of a suspect group. Tax records are customarily kept. The return is a public record. Thus, if a taxpayer could refuse to answer questions, why is it that Shapiro could not refuse to keep and produce records?

\section{The Real Meaning of the Required Records Doctrine}

\section{A. The Doctrine Restated}

It is far easier to point out the deficiencies in the Supreme Court's cases than to reconcile them. The fact is, however, that Sullivan, Shapiro and the trilogy all remain good law. To make sense of the cases, it is necessary to pay closer attention to the reporting schemes actually before the Court than to the Court's language.

If this is done, a system which requires that records be kept and produced upon request or subpoena appears most likely to be sustained if it satisfies the following criteria:

1. The government has general regulatory authority over the recorded activity. ${ }^{113}$

112274 U.S. 259 (1927).

112 Id. at 263-64; cf. Garner v. United States, 424 U.S. 648, 650-51 \& n.3 (1976) (requiring the defendant to invoke the privilege at the time of filing the return and not after the incriminating evidence had already been filed).

${ }^{113}$ Economic regulations like those involved in Shapiro traditionally require justification only on a rational basis in order to be upheld under the due process or equal protection clause. See, e.g., United States R.R. Retirement Bd. v. Fritz, 449 U.S. 166, 174-76 (1980) (due process); Williamson v. Lee Optical Co., 348 U.S. 483 (1955) (due process and equal protection). But if the government, for example, attempts to regulate prostitution and other illicit relationships by requiring travel records to be kept, see supra text accompanying note 69 , this measure might be judged an invasion of individual privacy requiring a showing of compelling state interest. See, e.g., Roe v. Wade, 410 U.S. 113, 155-56 (1973). 
2. The records are rationally related to the purpose of the regulation.

3. The government specifies both the records that must be kept and the rules that govern the activity. ${ }^{114}$

4. A person who chooses in the present to engage in the regulated activity may lawfully do so, as long as the rules governing the activity are followed and the required records are kept.

5. A person who conforms to the rules governing the activity and makes the required records need not fear self-incrimination as to acts performed before he became subject to the regulatory scheme.

These criteria suggest that the Supreme Court is willing to permit the government to use record-keeping as a device to regulate conduct which it has the power to regulate by other means. Even if the record-keeping requirement is intended to force those covered by it to obey the law, it will not violate the privilege against self-incrimination. The criteria also suggest, however, that the doctrine has definite limits. The Court is unwilling to tolerate record-keeping requirements that compel a person, prepared from the outset to conform his behavior to the rules, to disclose incriminating information about completed acts. The same is true of a regulatory system that seeks incriminating information which is not rationally related to valid regulatory goals.

Shapiro satisfies these criteria, while the trilogy does not. The government has the power to regulate prices in wartime. The government prescribed rules governing Shapiro's sales as a wholesaler and, for the most part, identified the records he was required to keep as to his current transactions. As long as Shapiro complied with the commercial rules and the record-keeping requirements, he could continue in his chosen business without fear of self-incrimination. Marchetti, Grosso, and Haynes were all in different situations. The Supreme Court found, and reasonably so, that they faced substantial risks of incrimination as to past conduct even if they did exactly what the various statutes required.

This does not mean that there was no self-incrimination risk in Shapiro, for there was one. Once Shapiro engaged in a transaction that violated one of the rules governing sales, the requirement

114 This criterion is important because it assures that one who is regulated is not compelled by the uncertainty of the requirement to make records that the government may not lawfully require. 
that he record the transaction then put him in the position of Marchetti, Grosso, and Haynes. Why, then, did the privilege against self-incrimination not protect him once he was in violation of the law against tie-in sales? If the cases are to be treated differently, it is important to recognize, as did the Court in the trilogy and as do the above criteria, that it might well matter whether a statute presents prospective risks rather than immediate ones. Although Justice Harlan, in his opinion in Marchetti, plainly rejected any absolute line between incrimination concerning past acts and incrimination concerning future ones, he never said that the difference was irrelevant. In the trilogy, his opinions found that the supposed prospective nature of the risk was illusory-that, in the terms of Kahriger and Lewis, the defendant had no "choice." Were this not true, it seems that Shapiro would have governed the trilogy.

The required records doctrine amounts to a form of government regulation which, Shapiro indicates, may be imposed as a condition of doing business. Presumably, the government could have required all sales of produce or other commodities to be made in a public arena with prices publicly announced. It could also have required the presence of an inspector whenever commodities were sold. The point is that the government can take strong measures to regulate a range of activities, especially when it relies upon the war power or focuses upon ordinary commercial exchange. By requiring records to be kept, the government imposes what may be a less onerous regime on commercial activity. Record-keeping and production are simply burdens of engaging in the activity. The required records criteria provide sufficient protection against the unbridled use of regulatory tools for prosecutorial ends.

Some proponents of an absolute reading of the privilege against self-incrimination would no doubt argue that the government ought to regulate without ever forcing anyone to risk incrimination. But this reading of the privilege leads to the inevitable conclusion that record-keeping and production can never be required in a regulatory scheme that also employs criminal sanctions. ${ }^{115}$ Shapiro illustrates why this is true.

115 So long as the underlying conduct is criminal, it would not matter whether the penalty for failing to keep and produce records is a criminal or civil penalty, such as license revocation or a civil fine. An absolute reading of the privilege would allow the government to impose sanctions for failure to produce evidence only if it offered use immunity. See Lefkowitz v. Turley, 414 U.S. 70 (1973) (invalidating sanction of cancellation of government contracts). 
Assume for a moment that Shapiro had been decided the other way and that the Court had held that a person may refuse to record prices in reliance on the privilege against self-incrimination. Would any grocery wholesaler have to keep records following such a decision? The answer must be no. No matter how clear the regulatory standards and how well-intentioned the wholesaler, there is always a chance that inadvertent violations will occur. Since any record might reveal an illegal sale, whether intentional or not, a person could refuse to keep any records on the ground that they might tend to incriminate him. One could argue that the chances of mistake and subsequent incrimination are too slight to warrant invocation of the privilege as to all transactions. But the more complicated the regulations, the more likely it is that any wholesaler who made a good faith effort to conform his conduct to the rules could nonetheless make a mistake. The possibility of incrimination is more than fanciful.

Furthermore, it would make little difference to assume that a wholesaler would not be in a position to assert the privilege as to all of his records. As soon as a wholesaler made a single sale at an unlawful price or one that might appear to be of questionable legality, he could use the privilege against self-incrimination as protection against any further record-keeping. A record of the illegal sale would plainly be incriminating. And all additional records might tend to show that the wholesaler was aware of the proper price on other occasions and intended to violate the law when he made the illegal sale. Recognition of the privilege would give a competitive edge to those who either violate the law or appear to be violating it, since they would be free not to bear the burden of keeping records. The competitive edge would be greatest for those who approached or crossed legal limits at the outset.

One solution that would treat all wholesalers the same would be to require record-keeping but to provide use immunity for all records actually kept. This solution, however, would make it impracticable to regulate prices by criminal sanction. Since the records would reveal the illegal act, the government would have to establish an independent source for any charge against a wholesaler. ${ }^{116}$ This would be difficult, if not impossible. Thus, the grant of immunity would completely undermine the deterrent effects of the criminal law.

Recognizing this problem, the Supreme Court has been unwill-

116 See Murphy v. Waterfront Comm'n, 378 U.S. 52, 79 n.18 (1964) (government must show that its evidence is untainted by testimony given under a grant of immunity). 
ing to require a grant of immunity as a condition of imposing a record-keeping or disclosure requirement upon individuals. In $\mathrm{Cal}$ ifornia $v$. Byers ${ }^{117}$ for example, the Court overturned a California Supreme Court decision that required use immunity as a condition of imposing an obligation on a driver to stop and identify himself at the scene of an automobile accident. Had the Court decided the case differently it would have effectively immunized many drivers from criminal prosecution for any driving offense, because the government would have had a difficult time demonstrating that its evidence was not a derivative product of the identification.

More recently, the Supreme Court decided Selective Service System v. Minnesota Public Interest Research Group, ${ }^{118}$ which presented a similar problem. Six anonymous students challenged a portion of a 1983 statute $^{119}$ that denies federal financial assistance under Title IV of the Higher Education Act of $1965^{120}$ to male students who fail to register for the draft. The students alleged that they intended to apply for assistance and needed financial aid, but that they had not registered for the draft. They claimed that they were in the unconscionable position of having to register, thus revealing that they had violated the law by not previously registering, or foregoing the needed financial assistance.

Should use immunity have been required? If it had, then the criminal penalties for nonregistration would become largely unenforceable against late registrants. The government would have to prove that none of its evidence against anyone whom it prosecutes is derived from the late registration. ${ }^{121}$ If the late registration receives any publicity at all, the burden would be almost impossible to meet. Despite this, Justice Marshall argued in dissent that the privilege attaches, so that use immunity must be granted to students who register in order to seek financial assistance. ${ }^{122}$ But the majority held that the privilege does not apply, even though it recognized that a student who discloses his date of birth on a late registration reveals a potentially incriminating fact. ${ }^{123}$

117402 U.S. 424 (1971). Byers is treated at greater length infra at notes 143-48 and accompanying text.

118104 S. Ct. 3348 (1984).

119 Department of Defense Authorization Act of 1983, Pub. L. No. 97-252, § 1113(a), 96

Stat. $718,748$.

${ }^{120} 20$ U.S.C. $\$ \S 1070-1089$ (1982).

${ }^{121}$ See supra note 116 and accompanying text.

122104 S. Ct. at 3368 (Marshall, J., dissenting).

${ }^{123}$ Id. at 3358. The five criteria listed earlier, see supra notes 113-15 and accompanying text, suggest that a different result could be reached as to students who were due to register for the draft before the passage of the 1983 financial aid statute. When they decided not to 
Cases like Shapiro, the trilogy, and Minnesota PIRG serve to remind us that the privilege against self-incrimination is not intended to make it easier for people to commit criminal acts. To be sure, people in Shapiro's situation are put between a rock and a hard place. They must follow the law with respect to their business and they must keep records. Should they break the law, they face sanctions whether they record the violation or fail to record it. This system puts pressure on people to conform their behavior to legal requirements. The Supreme Court in Shapiro, and perhaps in the trilogy, declined to find this pressure violative of the privilege against self-incrimination.

The requirement that a record be made and produced serves a regulatory function that could be accomplished in other ways. But the required records doctrine is limited. It does not authorize the government to compel a person to answer questions about past activity. To do so would go beyond prospective regulation and focus on past events, which would result in what has traditionally been

register, they had no notice that nonregistration might result in a loss of financial aid. But the opposing arguments are also strong. Students had no guarantee that the federal government would continue to offer financial aid on the same terms. Furthermore, young people required to register may well have realized that questions concerning registration could be asked were they to apply for government jobs. Thus, the idea that failure to register might cause future difficulties in securing government benefits would hardly have been surprising to those who declined to register.

In arguing that immunity was required, the dissenting justices concluded that a person who registers late in order to qualify for financial aid must inevitably incriminate himself. The majority, in contrast, thought it premature to decide this question, since the plaintiffs had not reached the point of registering and there had been no opportunity to consider whether registration would require incrimination. By analogy to United States v. Sullivan, 274 U.S. 259 (1927), discussed supra at text accompanying notes 111-12, in which Justice Holmes implied that Sullivan could have refused to answer incriminating questions on his tax return, it appears that a person who registered late might refuse to answer any question on the registration form about his birthdate. The students were therefore not in exactly the same situation as Shapiro. Shapiro was required to comply with a subpoena and to produce books and records that did incriminate him. He could not remove material from the books and records without violating the record-keeping requirements.

It is of course true that the invocation of the privilege by Sullivan or by the students might have raised the suspicions of government officials. But the privilege has never been thought to require that officials pay no mind to its invocation. When police officers encounter a suspect who indicates that he does not want to answer questions and will rely upon his privilege not to answer, there is no legal bar to the officers' deciding that they should investigate further in the belief that the suspect is hiding something. The privilege prevents the government from gathering certain kinds of information in a particular way; it does not bar it from seeking to gather the same information in other ways once the privilege is invoked. This is one of the most powerful pieces of evidence that, as will be noted in the next paragraph of the text, the privilege is not designed to make it easy for people to commit crimes and to escape detection. 
viewed as the archetypical instance of self-incrimination. ${ }^{124}$

\section{B. The Lower Court Cases}

It is helpful in understanding the application of the five criteria listed earlier to compare two cases that have been recently decided in lower courts. In each case, the court reached the results required by the criteria. In In re Doe, ${ }^{125}$ a grand jury subpoenaed prescription forms from a psychiatrist under investigation for illegal prescription of drugs. The Second Circuit had no difficulty in holding that the prescription forms were required records that the doctor could be compelled to produce. Using the criteria set forth above, it appears that the court was correct. The psychiatrist knew what conduct was expected; state law required the records to be kept; and he would not have incriminated himself had he lawfully prescribed drugs and kept the required records.

The court had more difficulty dealing with patient files, which were also subpoenaed. The New York Board of Regents, charged with regulating the medical profession, had established that a doctor who failed to maintain a record reflecting evaluation and treatment for each patient would be subject to disciplinary action or punishment for unprofessional conduct. A majority of the court found that the privilege did not apply because the patient records were within Shapiro. ${ }^{126}$ Judge Friendly dissented from this aspect of the judgment, arguing that patient records were required to be kept only "for the benefit of patients and professional licensing authorities," not to aid enforcement of narcotics laws. ${ }^{127}$

Should Judge Friendly's argument have prevailed? Professor Meltzer foresaw in 1951 the problem of "[w]hether records required under a particular statute are unprivileged only in the proceedings contemplated by the particular statute or whether the required records are unprivileged generally."128 $\mathrm{He}$ argued that the

224 It is this limitation on the required records doctrine that answers criticisms that the doctrine would permit the government to compel a person to give up all of his protection under the privilege. For an example of that criticism, see Note, Constitutional Limits on the Admissibility in the Federal Courts of Evidence Obtained from Required Records, 68 Harv. L. REv. 340, 341-42 (1954).

126 711 F.2d 1187 (2d Cir. 1983).

${ }^{128}$ A similar result was reached in In re Kenny, 715 F.2d 51 (2d Cir. 1983) (medical and X-ray records). See also United States v. Rosenberg, 515 F.2d 190 (9th Cir.), cert. denied, 423 U.S. 1031 (1975) (prescription records). The Second Circuit applied the same reasoning to lawyers in United States v. Silverman, 449 F.2d 1341 (2d Cir. 1971), cert. denied, 405 U.S. 918 (1972).

${ }^{127}$ In re Doe, 711 F.2d at 1197 (Friendly, J., concurring in part and dissenting in part).

${ }^{128}$ Meltzer, supra note 12 , at 718-19. 
more significant invasion of privacy takes place when the documents are required to be produced. That intrusion may only be justified by the purposes of the regulatory scheme that requires the records to be kept. Meltzer argued, however, that once the documents have been produced, later collateral uses by other agencies or law enforcement authorities should be permitted in the interest of "sensible governmental cooperation."128

Professor Meltzer's position is more restrained than necessary under current federal constitutional law. If the required records criteria are satisfied, an individual who keeps records has no privilege against self-incrimination with regard to those records. If this were not the case, the government could not punish the individual for failing to keep the records. And because the records are not protected, no fifth amendment "privacy" interest is invaded by requiring that person to produce them. Thus, the majority was correct.

In re Doe sustained the required records provisions. Bionic Auto Parts \& Sales, Inc. v. Fahner ${ }^{130}$ reached a different result. Illinois motor vehicle statutes criminalized the possession, sale, or disposal of part or all of a vehicle whose identification number had been removed or falsified. Knowledge of removal or falsification rendered the conduct a felony; ${ }^{131}$ the conduct was otherwise a misdemeanor. ${ }^{132}$ Motor vehicle regulations required dealers in automotive parts to record any alteration, defacing, or removal of a serial number or identification mark from any used vehicle or auto part. ${ }^{133}$ The Seventh Circuit analyzed Shapiro and the trilogy and granted injunctive relief against enforcement of the record-keeping requirement on self-incrimination grounds. ${ }^{134}$

The court in Bionic Auto Parts reached the correct result under the criteria. Bionic Auto Parts differed from Shapiro in two vital respects. First, all the actions that dealers were required to record were illegal. Second, the substantive statutes were so written as to make it impossible to stay in the regulated business without risking self-incrimination. The record-keeping requirement came into play the moment a dealer became aware of falsification

$120 I d$.

130 721 F.2d 1072 (7th Cir. 1983).

131 Illinois Vehicle Code § 4-103(a)(4), Ill. REv. Stat. ch. 951/2, § 4-103(a)(4) (Supp. 1984).

132 Illinois Vehicle Code § 4-102(a)(3), Ill. Rev. Stat. ch. 951/2, § 4-102(a)(3) (Supp. 1984).

133 See Bionic Auto Parts, 721 F.2d at 1081.

134 Id. at 1081-84. 
or removal of identification. ${ }^{135}$ In some cases, a dealer may have known of alterations from the moment of possession; in others, the alteration may only have become apparent later upon close inspection. In either case, however, possession of the altered item in the period before recordation was criminal, as was any attempt to dispose of the item upon discovery of its altered state. Thus, the only way to avoid self-incrimination as to past criminal possession was to disobey the record-keeping requirement. Such a "choice" is beyond the proper scope of the required records doctrine.

This is not to say that no alternative regulatory scheme would be sustained. It might well be acceptable to require registration of all altered parts as long as possession did not become a crime until a specified period, sufficient to permit inspection, had passed. Similarly, it might be acceptable to require dealers to refuse to accept delivery of an auto or its parts until they have recorded a description of all parts, noting the presence or absence of identification numbers, and to make it a crime both to violate the reporting requirement and to accept delivery of altered parts. Such requirements would satisfy valid regulatory interests while simultaneously permitting dealers to deal in those parts they may legally possess without fearing that record-keeping will incriminate them. It is both the absence of a valid regulatory purpose and the unavoidable self-incrimination that makes the scheme in Bionic Auto Parts particularly suspect.

There is no doubt, as Professor Meltzer predicted in 1951, ${ }^{136}$ that the required records doctrine has developed along with government's expanding regulatory and revenue powers. It has permitted the government to investigate and control behavior, particularly in economic matters, in ways that would be impossible if the privilege against self-incrimination were held to bar requirements of record-keeping and production. Professor Meltzer suggested that as long as the due process clause, the first amendment, and the fourth amendment protect fundamental interests, the required records doctrine could be implemented without disturbing the core values of the privilege against self-incrimination. ${ }^{137}$ Looking at the cases that have since been decided, it appears that he was correct.

${ }^{135}$ Id. at 1081 n.6.

${ }^{136}$ Meltzer, supra note 12, at 728.

${ }^{137}$ Id. Presumably he would include today the equal protection clause, which had not been well developed by the courts when he wrote in 1951 . 


\section{Required Disclosure and Further Applications of the PRIVILEge}

As the previous discussion shows, one of the messages suggested by the required records doctrine is that the privilege against self-incrimination is not intended to make it easier for people to commit criminal acts. A second lesson that is confirmed in related cases is that a person who does commit a criminal act and who intends to rely on the privilege is not entitled to a special exemption from duties imposed by law on the public generally or on noncriminals within the regulated class.

One of the earliest and best illustrations of this point is United States v. Sullivan, ${ }^{138}$ where the Court upheld a conviction for failure to file a tax return. The Court's decision-that a person could not escape the burden of taxation imposed upon all persons earning income in the United States simply because that person might have committed a criminal act—-teaches a broader lesson: no one is to be relieved by the privilege of duties generally applicable to persons similarly situated.

This lesson is clearly applicable to many current questions about how the privilege should apply in a particular context. For example, some commentators have expressed concern about the requirement that aliens register with the Attorney General each year. ${ }^{139}$ This requirement undoubtedly makes it difficult to stay in the country illegally. But the first lesson of the required records doctrine is that this is not an impermissible result. And, under the lesson of Sullivan, once the requirement is accepted as applicable to legal entrants, illegal aliens who have smuggled themselves into the United States have no right to an exemption from the registration requirement on self-incrimination grounds. They too must comply.

A similar point can be made about statutes or ordinances requiring individuals to give their correct names and addresses when registering in hotels. To the extent that hotels need protection against damage to their property, they have a right to know the parties with whom they deal. This is true regardless of whether the guest, by disclosing his or her real name, faces a risk of incrimination. Laws that prohibit fraudulent misrepresentation thus are not likely to violate the privilege against self-incrimination, although 
some have thought that these laws raise grave problems. ${ }^{140}$

If the Sullivan-type explanation of the reason why disclosure may be required without violating the privilege against self-incrimination is accepted, it would appear that the statutory requirement that a person provide written notice to an airline before shipping firearms in foreign commerce would also be upheld. ${ }^{141}$ The reason is not that a private person rather than the government is receiving the disclosure ${ }^{142}$ but that it is in the public interest for the airline to know whether it is carrying firearms. Just as no person has a right to mislead an innkeeper, no person has a right to mislead an airline about the nature of the goods it carries even when disclosure might incriminate. So long as disclosure is required generally of all individuals engaging in a regulated activity, the existence of a risk of incrimination does not give rise to a special exemption from the disclosure requirement.

The difficulty of accommodating fifth amendment concerns within an effective regulatory scheme is evident in California $v$. Byers. ${ }^{143}$ There, a majority of the Court, without agreeing on an opinion, ${ }^{144}$ upheld the prosecution of Byers for failing to stop and identify himself as required by California law after an accident resulting in damage to property. ${ }^{145}$ Although the California Supreme Court had read a use immunity protection into the statute in the belief that the privilege required such immunity, the United States Supreme Court found the protection unnecessary. The Chief Justice's plurality opinion strained to find the state's requirement insufficiently incriminating and insufficiently testimonial to warrant the protection of the privilege. ${ }^{146}$ The analysis is so tortured that it

${ }^{140}$ See, e.g., id. at 141-42. One could argue that it would be better to leave the decision whether to require correct names and addresses to individual innkeepers. But this argument is irrelevant to a self-incrimination analysis. If it is acceptable for a statute to require a person to use her correct name and address if an innkeeper so requires, then it is permissible to place the force of law behind an across-the-board disclosure requirement. Although such a statute may be considered paternalistic, it can also be seen as an efficient device to save innkeepers the costs of invoking the law's protections.

14118 U.S.C. \& $922(\mathrm{e})(1982)$.

${ }^{142}$ Compare United States v. Wilson, 721 F.2d 967, 974 (4th Cir. 1983) (considering this distinction significant since there is only a "mere possibility that a common carrier might provide incriminating information to the government"), with United States v. Flores, 753 F.2d 1499, 1502 (9th Cir. 1985) (rejecting this distinction since "any number of carriers may cooperate with law enforcement officials . . . although not required to do so").

143402 U.S. 424 (1971).

144 Chief Justice Burger's plurality opinion was joined by Justices Stewart, White and Blackmun. Id. at 425. Justice Harlan concurred only in the judgment. Id. at 434.

${ }_{145}$ CAL. Veh. Code $\S 20,002$ (a)(1) (West Supp. 1985).

${ }^{146}$ See Byers, 402 U.S. at 431-34. 
cannot be considered persuasive, and a majority of the Court actually rejected it. ${ }^{147}$

Justice Harlan's concurring opinion offers the only acceptable explanation for the result. The California statutory scheme imposed civil liability on drivers for all accidents, while simultaneously utilizing criminal sanctions for certain moving violations. Both the scheme of universal civil responsibility and the selective use of criminal sanctions were, in Justice Harlan's view, sufficiently important to be permitted to coexist even though mandatory selfreporting for civil purposes clearly exposed the driver to some risk of incrimination. He recognized that this result cannot be justified by an appeal to the "disingenuous" finding that the actual, statistical risks of self-incrimination are low. ${ }^{148}$ Justice Harlan relied in part on the fact that self-reporting still leaves the government with the considerable burden of proving the criminality of the conduct and its causal connection to the property damage. In the end, however, he admitted that the decision of the case required making a judgment about the role of the privilege in the modern world.

California could have established a different requirement. It could, for instance, have made it a crime to move a vehicle from the scene of an accident resulting in damage to any property until authorized by a police officer. California might have added to such a statute an additional requirement that any witness must remain at the scene of an accident involving property damage until excused by a police officer. To comply, a person would have to remain present but would not have to admit to having been a witness. These requirements would have avoided self-incrimination, since no testimonial act would have been required. While these alternatives would avoid privilege problems and be at least as effective as the California scheme, they would be more burdensome to drivers as a group. The balance struck by the California statute . might well be considered acceptable.

Byers is also one of many situations in which the availability of use immunity is irrelevant. Providing use immunity to someone who makes a self-incriminating statement in public would negate the criminal sanction for all practical purposes. Once the immunized statement is made, the government may find it impossible to show that its prosecution was not affected by it. The more public

${ }^{147}$ See id. at 435-36, 438-39 (Harlan, J., concurring in the judgment); id. at 460-63 (Black, J., dissenting, joined by Douglas and Brennan, JJ.); id. at 468-73 (Brennan, J., dissenting, joined by Douglas and Marshall, JJ.).

14s Id. at 442 (Harlan, J., concurring). 
the statement, the more onerous the burden on the government. Use immunity may be a reasonable price to impose on the government when information is exclusively in the hands of a regulatory agency that can control prosecutorial access; but in situations like Byers, the measure of the price is the loss of the criminal sanction.

\section{Records of Corporations and Other Entities}

The previous sections' discussion of the policies underlying the required records doctrine has implications for the application of the privilege against self-incrimination not only to individuals but also to corporations and other entities faced with a regulatory scheme requiring disclosure of potentially incriminating information. This is no accident. The required records doctrine was itself influenced by the prior treatment of corporate records under the fifth amendment, ${ }^{149}$ and the areas of law have a common history and rationale. Once the doctrines applied to corporations and other entities, like the required records doctrine, are seen as responses to the expansion of government regulation, the need for reform becomes apparent.

\section{A. Corporations}

It has been hornbook law since the Supreme Court decided Hale $v$. Henkel ${ }^{150}$ that corporations may not invoke the privilege against self-incrimination. After Hale, the Court held in Wilson $v$. United States ${ }^{151}$ that corporate officers and agents in possession of corporate records must produce them in response to a subpoena, even though the records might incriminate them personally. ${ }^{162}$ Wilson, which was relied upon by the Court in Shapiro, ${ }^{153}$ laid a foundation for subsequent cases that embellished its rule. ${ }^{154}$

Although it is settled that corporations cannot claim the privilege, the reason why they cannot has been poorly developed. In 35-37.

149 See Wilson v. United States, 221 U.S. 361 (1911); supra text accompanying notes

1so 201 U.S. 43 (1906).

161221 U.S. $361,381-86$ (1911).

${ }^{182} I d$. at 381-86. Wilson involved a subpoena issued to the corporation. A companion case, Dreier v. United States, 221 U.S. 394 (1911), indicated that the result would be the same whether the subpoena was directed to the corporation or to an officer of the corporation, as long as it sought corporate records. Id. at 399-400.

163335 U.S. 1, 16-19 (1948).

154 See, e.g., Grant v. United States, 227 U.S. 74 (1913) (no privilege as to records in possession of attorney of former sole shareholder); Wheeler v. United States, 226 U.S. 478 (1913) (no privilege as to records of dissolved corporation). 
Hale, the Supreme Court recognized that the words "no person" in the privilege portion of the fifth amendment ${ }^{155}$ do not on their face indicate the status of corporations. Since the Court held in Hale that the "houses, papers, and effects"156 of a corporation are protected by the fourth amendment, ${ }^{157}$ one might have thought that a corporation would be a "person" within the protection of the privilege against self-incrimination as well. Not so, said the Court.

The Hale Court reasoned that the Bill of Rights must be interpreted to give corporations the protections warranted and no more. The Court concluded that a corporation could not claim the privilege, since it had no right to exist and was subject to the visitation power of the state that created it. ${ }^{168}$ As the same reasoning could have been used to deny corporations fourth amendment protection, or the protection of almost any amendment, the Court begged the question of why the privilege against self-incrimination should be denied to corporations that were not denied other rights. ${ }^{159}$

Nonetheless, once the decision was made to deny the privilege, the Court could easily justify the subpoena of corporate records in the possession of corporate officers who stood to be incriminated by their contents. ${ }^{160} \mathrm{Had}$ the Court decided otherwise, the visitation power, which is the government's power to make public inspection of corporate records, would have been hampered by privilege claims raised by corporate officers.

In the end, the Court in Hale struck a sensible compromise in its treatment of corporations. Enforcement of economic regulations is uniquely dependent on documentary evidence. Constitutional doctrines in force when Hale was decided severely restricted the

Iss "No person ... . shall be compelled in any criminal case to be a witness against himself . . . " U.S. ConsT. amend. V.

${ }^{136}$ U.S. ConST. amend. IV (emphasis added).

${ }^{187}$ Hale, 201 U.S. at 76.

188 Id. at 74-75.

150 The Court had already given corporations the protection of the due process clause of the fourteenth amendment. See Gulf, Colo. \& S.F. Ry. v. Ellis, 165 U.S. 150, 154 (1897). Since a corporation is also a "person" within the protection of the due process language in the fifth amendment, it is apparent that the Court was not bound to deny corporations the fifth amendment privilege.

${ }^{160}$ At the time of Hale and Wilson, the right to claim the privilege depended for the most part on ownership or private property rights in documents. Thus, in Wilson, the Court reasoned that "the physical custody of incriminating documents does not of itself protect the custodian against their compulsory production," since "[i]t may yet appear that they are of a character which subjects them to the scrutiny demanded and that the custodian has voluntarily assumed a duty which overrides his claim of privilege." 221 U.S. at 380 . 
federal government's access to documents. ${ }^{161}$ The fourth amendment was held to bar the government from searching for and seizing private papers that were "mere evidence" of crime. ${ }^{162}$ The fifth amendment was understood to prohibit the subpoena of private documents voluntarily made. ${ }^{163}$ Had Hale been decided differently, cases arising under the Sherman Act, as had Hale itself, would have been almost impossible to prosecute. ${ }^{164}$ By giving corporations fourth amendment protection, the Court protected them from forcible invasion by government officers; by denying them fifth amendment protection, it assured access by the government to corporate papers.

\section{B. Other Entities and the Privilege}

For many years, associations of individuals were assumed to be able to claim the privilege even though corporations could not. This assumption gave way with the Supreme Court's holding in United States $v$. White. ${ }^{185}$

White arose from a grand jury investigation of a union local. The grand jury subpoenaed the union's books from its president, who claimed the privilege on the ground that the books might tend to incriminate the local, himself as an officer, and himself individually. The district court held the president in contempt, but the court of appeals reversed by a divided vote. ${ }^{166}$ The majority held that the local's records belonged to all its members. If the books would tend to incriminate the member who held them, that member was privileged not to produce them. ${ }^{167}$

The Supreme Court reversed. Justice Murphy's opinion for the Court reasoned that "[s]ince the privilege against self-incrimination is a purely personal one, it cannot be utilized by or on behalf of any organization, such as a corporation."168 Although he recognized that the state has no visitation power over unincorpo-

161 Since the fourth and fifth amendments had not yet been incorporated into the fourteenth amendment, see Mapp v. Ohio, 367 U.S. 643 (1961) (incorporating fourth amendment); Malloy v. Hogan, 378 U.S. 1 (1964) (incorporating fifth amendment), corporate records were not off limits to the states, at least not as a matter of federal law.

162 Warden v. Hayden, 387 U.S. 294, 300-10 (1967), changed the rule by rejecting the distinction between "mere evidence" and "fruits of crime" or contraband for fourth amendment purposes.

${ }^{163}$ See supra note 21 and accompanying text.

${ }^{104}$ This was noted by the Court. See Hale, 201 U.S. at 74.

105322 U.S. 694 (1944).

186137 F.2d 24 (3d Cir. 1943), rev'd, 322 U.S. 694 (1944).

137137 F.2d at 26.

${ }^{183} 322$ U.S. at 699. 
rated organizations, he found that "the absence of that fact as to a particular type of organization does not lessen the public necessity for making reasonable regulations of its activities effective, nor does it confer upon such an organization the purely personal privilege against self-incrimination."168

The main virtue of the Court's opinion in White is its candid opposition to allowing the use of the privilege to "protect economic or other interests of such organizations so as to nullify appropriate governmental regulations."170 The Court correctly saw that the government's need to regulate did not depend on the accident of the form of organization chosen by the regulated business. Nonetheless, the test set forth does not adequately correspond to the Court's valid regulatory concerns.

The test applied by the Court in White has been used many times since:

The test . . . is whether one can fairly say under all the circumstances that a particular type of organization has a character so impersonal in the scope of its membership and activities that it cannot be said to embody or represent the purely private or personal interests of its constituents, but rather to embody their common or group interests only. If so, the privilege cannot be invoked on behalf of the organization or its representatives in their official capacity. ${ }^{171}$

The unsuccessful union president in White has not stood alone in defeat. When the Court's test is applied to virtually any organization, the organization loses. ${ }^{172}$

The strongest attack on this test is made by offering the following hypothetical case: Thief $A$ keeps a running record of the thefts and the amount of the proceeds for which he and $B$ have been responsible. $A$ reproduces a copy of the records for $B$ so that each has a copy. Each keeps his copy at his home. According to the Court's test, each may claim the privilege as to his copy. But if they form a partnership and jointly prepare the records, neither may claim the privilege. Surely this is a little odd and requires explanation.

169 Id. at 700.

$170 I d$.

171 Id. at 701.

172 See, e.g., Bellis v. United States, 417 U.S. 85 (1974) (dissolved law partnership). 
C. Undermining the Rationale for Denying Entities the Privilege

In White, the Court stressed that the privilege against selfincrimination ought not to be used to "protect economic or other interests of such organizations so as to nullify appropriate governmental regulations." ${ }^{173}$ But the importance of denying the privilege to corporations and other entities is often exaggerated. Under the required records doctrine, corporations can be compelled, notwithstanding the privilege, to keep and produce records. Thus, government regulation of corporations would be possible even in the face of the privilege. The denial of the privilege to organizations is nonetheless important for two reasons: first, it permits the government to subpoena records that it did not require the corporation to make; second, it permits the government to impose corporate record-keeping requirements that fail to meet the criteria of the required records doctrine. ${ }^{174}$

It is understandable that the government would want to have access to all entity records for regulatory purposes. But the notion that it is necessary completely to deny the privilege to entities and their officers has been undermined by the Court's relatively recent decisions in Andresen v. Maryland, ${ }^{175}$ Fisher v. United States, ${ }^{176}$ and United States v. Doe. ${ }^{177}$ In these cases, the Court has radically altered the traditional assumption that the privilege attaches to all self-incriminatory private papers. Under the Court's new doctrine, a claim of privilege to resist a subpoena of private documents that have been voluntarily made may not be based on the tendency of the content of those documents to incriminate their maker. ${ }^{178}$ For the privilege to attach, the government must compel a testimonial act. Since the contents of voluntary documents are not "com-

${ }^{173} 322$ U.S. at 700.

174 The government could thus compel corporations to make and reveal records of past acts even though the records plainly incriminate the corporation. This would be outside the permissible scope of required records.

175427 U.S. 463 (1976).

178425 U.S. 391 (1976).

177465 U.S. 605 (1984).

${ }^{178}$ See Doe, 465 U.S. at 612-13 (business records); Andresen, 427 U.S. at $472-73$ (business records); Fisher, 425 U.S. at $408-10$ (worksheets made by taxpayer's accountant). Justice O'Connor's concurring opinion in Doe states that the fifth amendment "provides absolutely no protection for the contents of private papers of any kind." 465 U.S. at 618 . Justice Marshall, joined by Justice Brennan, expressed the view that the Court had not yet decided whether the contents of some private papers might be protected by the amendment. Id. at 618-19 (Marshall, J., concurring in part and dissenting in part). There is little doubt that the contents of the kind of papers associated with businesses and entities will be outside the protection of the self-incrimination privilege under all of these views. 
pelled," the Court now requires that the compelled act of production itself be self-incriminating for the privilege to be invoked. ${ }^{179}$ If there is no realistic possibility that production would tend to incriminate, ${ }^{180}$ or if use immunity for the act of production is conferred, ${ }^{181}$ the privilege claim will not prevail.

In the face of these new decisions, it might be time to reexamine the holding in Wilson that a corporate officer may not invoke the privilege to resist the subpoena of corporate documents tending to incriminate him. ${ }^{182}$ As long as the focus of the cases was on the contents of the documents, the Court was not prepared to permit individuals to claim the privilege, for the privilege might have provided too much protection for too many people with respect to documents that were not their own. The act of production by an individual is personal, however. It can be highly incriminating. Since the Court has limited Wilson by holding in Curcio $v$. United States $^{183}$ that a custodian of an entity's records may not be compelled to answer questions about the whereabouts of the records, it would be appropriate for the Court to provide similar protection for a custodian's act of production in response to a subpoena. This would protect individuals from incrimination resulting from their own acts. It would not protect corporate records. ${ }^{184}$

179 The Court's shift has been criticized, in part because it presents difficult linedrawing problems. One reading of Fisher is that the Court should assume that the act of production is insufficiently incriminating to justify a claim of privilege except "when the subpoena requests material the mere possession of which is criminal." Heidt, The Fifth Amendment Privilege and Documents-Cutting Fisher's Tangled Line, 49 Mo. L. RBv. 439, 484 (1984). This suggestion appears to be a particularly bad idea. If a witness would not have to answer questions as to whether he possesses certain documents, whether he knows the nature of them, whether the documents belong to some specific person, and many similar questions, there is no reason why he should be compelled to answer such questions implicitly by producing the documents. Ruling on privilege claims is never easy, since courts must be concerned lest they compel the very disclosure that they seek to avoid in the process of ruling on a claim. Bright-line rules are no more justified with respect to documents than with respect to oral testimony.

${ }^{180}$ See, e.g., Fisher, 425 U.S. at 412.

181 See Doe, 465 U.S. at 617 \& n.17 (1984).

182 See supra note 160 and accompanying text.

183354 U.S. 118 (1957).

184 One court of appeals has been attracted by a similar idea. See In re Grand Jury Matter, 768 F.2d 525 (3d Cir. 1985) (en banc). By a vote of six to five, a majority of the court held that the sole owner of an accounting corporation could invoke his privilege against self-incrimination to prevent being compelled by subpoena to authenticate corporate records, the content of which might incriminate him personally. The majority reasoned that Fisher and Doe had limited the applicability of earlier cases concerning entities and their officers when production of documents involved self-incriminatory communication by the officers. Id. at 527-28. Three dissenting judges observed that neither of these cases had involved entities and relied upon Bellis v. United States, 417 U.S. 85 (1974), which had stated: 
D. Final Thoughts on the Privilege for Corporations and Other Entities

As noted earlier, however, this reform would leave one circumstance in which the denial of the privilege to entities makes an important difference: where the government seeks to compel them to make and produce records that would undoubtedly tend to incriminate as to past acts. ${ }^{185}$ These records do not meet the criteria set forth in the required records doctrine, so their production could not be compelled under that approach. ${ }^{186}$ It thus remains necessary to discover why entities, but not individuals, may be compelled to create documents that may, and in some circumstances surely will, incriminate them.

We have seen that the Court's explanation for the treatment of entities has not been entirely satisfactory. A better explanation finds support in Justice Murphy's language in White:

\footnotetext{
"[A] long line of cases has established that an individual cannot rely upon the privilege to avoid producing the records of a collective entity which are in his possession in a representative capacity, even if these records might incriminate him personally." Id. at 88 , cited in 768 F.2d at 532 (Garth, J., dissenting). Two other judges concurred in the result on the ground that the case involved testimonial incrimination as well as production of documents, but agreed that the dissenting judges' view of entity privilege was correct. 768 F.2d at 530 (Becker, J., concurring). An approach similar to the majority's is evident in In re Grand Jury 83-8 (MIA) Subpoena Duces Tecum, 611 F. Supp. 16, 21-25 (S.D. Fla. 1985).

Two other courts of appeals have disagreed with the Third Circuit's approach. See In re Grand Jury Proceedings, 771 F.2d 143 (6th Cir. 1985) (en banc); In re Two Grand Jury Subpoenae Duces Tecum, 769 F.2d 52 (2d Cir. 1985). The Second Circuit's decision is somewhat confusing. The district court had held that the appellant, the target of a grand jury investigation, did not have to produce the requested records, but that the corporation-through any employee-would still have to comply with the subpoena as modified. 769 F.2d at 54. The court of appeals admitted that "[i]n certain limited circumstances, . . . an individual may have a fifth amendment privilege against being personally compelled to produce corporate documents," $i d$. at 57 , but went on to state that Doe had not changed the law with regard to the corporation itself. Like the dissenters in the Third Circuit, the court relied on Bellis. Id. at 59. Thus, the opinion is internally consistent. This is not the case with the Sixth Circuit's opinion. By a 9-2 vote, that court held that nothing in Fisher or Doe changed the law regarding entities as it was stated in Bellis. $771 \mathrm{F.2d}$ at 145-47. The two dissenting judges disagreed. Id. at 148-49.
}

This article suggests that the law should be changed to provide protection to the individual. If this change is to be made, the Supreme Court almost surely will have to make it. The reasoning of the Third Circuit majority is sensible as a matter of policy, but the dissenters more accurately describe the current state of the law.

${ }^{185}$ See supra note 174 and accompanying text.

${ }^{188}$ This is why it is incorrect to suggest that the required records doctrine is unnecessary after the recent Supreme Court cases with respect to production of documents, an argument made in Note, In re Doe: Required Records and the Fifth Amendment, 16 Cons. L. REv. 1021, 1041 (1984). 
The constitutional privilege against self-incrimination is essentially a personal one, applying only to natural individuals. It grows out of the high sentiment and regard of our jurisprudence for conducting criminal trials and investigatory proceedings upon a plane of dignity, humanity and impartiality. It is designed to prevent the use of legal process to force from the lips of the accused individual the evidence necessary to convict him or to force him to produce and authenticate any personal documents or effects that might incriminate him. Physical torture and other less violent but equally reprehensible modes of compelling the production of evidence are thereby avoided . . . . ${ }^{187}$

Herein lies the real justification for denying entities the benefit of the privilege: entities cannot be tortured, they cannot perjure themselves, and they cannot have religious beliefs. In short, none of the concerns that gave birth to the privilege and that explain its continued vitality is applicable to entities.

There is one possible objection to this explanation. If a purpose of the privilege is to safeguard the rights of the defendant within an adversarial system, perhaps the government should be required to shoulder the entire load in a prosecution and not have the advantage of being able to compel self-incriminating disclosure. Yet even this argument rests in large measure on a perceived right to individual autonomy, which suggests that the balance between the individual and the state ought to take a certain shape. ${ }^{188}$ Pitting an entity against the government, however, is to pit entity against entity. One may well conclude that this is not offensive to the values that underlie the privilege.

\section{ConCLUSION}

The privilege against self-incrimination remains a fundamental protection for the individual against government investigations. The paradigm protection of the privilege arises when a suspect, or even a witness, refuses to answer questions in a formal proceeding. Outside of the courtroom, the privilege raises many complicated questions. The answers that we provide are informed by the his-

187 United States v. White, 322 U.S. 694, 698 (1944).

${ }^{18 s}$ Interestingly, Wigmore, as the Court noted in Murphy v. Waterfront Comm'n, 378 U.S. 52 (1964), said that the government should be required "in its contest with the individual to shoulder the entire load." $8 \mathrm{~J}$. WIGMORE, supra note 11, § 2251, at 317 (emphasis added), quoted in Murphy, 378 U.S. at 55. 
tory of the privilege and the policies that it serves, and change with a changing world.

This discussion of required records and other related issues offers some lessons about the role of the privilege. One is that the privilege is not intended to facilitate criminal activity. A second is that those who would rely on the privilege are not excused from societal obligations imposed on all who are similarly situated. Thus, reliance on the privilege will not solve all the problems of people who tread close to or cross the line demarcating illegal conduct. It never has, and there is little apparent popular support for the proposition that it should.

The most important lesson, though, is that the "cases attempting to capture the 'purposes' or 'policies' of the privilege demonstrate the uncertainty of the mandate."189 Chief Justice Warren, who authored the ringing quotation that began this article, dissented in the 1968 trilogy. Justice Harlan wrote the trilogy, but he provided the crucial vote denying the privilege in California $v$. Byers. Justice Brennan dissented in Byers, but he joined Justice Harlan in the trilogy while insisting that Shapiro and Sullivan remained good law.

Those who ignore the history of the privilege against selfincrimination may believe that it is possible to state a single bright-line rule to handle all cases, and that the government should never be able to pressure anyone to do anything that might appear to be incriminating. The analysis offered here reflects a judgment that Justice Harlan was correct when he said that " $[t]$ he policies behind the privilege are varied, and not all are implicated in any given application of the privilege." ${ }^{190}$ Choices must be made.

In 1951 Professor Meltzer observed that the privilege against self-incrimination must be assessed against the regulatory system that a nation adopts. ${ }^{191}$ Thus far the cases have proved him correct. Have they resulted in an unacceptable emasculation of the privilege? Or have they made the privilege fit fairly well into a complex legal system? Each person who confronts this issue, like each judge called upon to rule, must provide his or her own answer.

${ }^{189}$ California v. Byers, 402 U.S. 424,450 (1971) (Harlan, J., concurring).

190 McGautha v. California, 402 U.S. 183, 214 (1971).

192 See Meltzer, supra note 12, at 728. 